\title{
Epidemiological Features of Patients with Craniomaxillofacial Fractures: A Single Centre Study
}

\author{
Mohamed Khallaf ${ }^{*}$, Mohammed S. Shahine ${ }^{2}$ \\ ${ }^{1}$ Department of Neurosurgery, Faculty of Medicine, Assiut University, Assiut, Egypt \\ ${ }^{2}$ Maxillo-Facial Surgery Unit, General Surgery Department, Faculty of Medicine, Assiut University, Assiut, Egypt \\ Email: ^khallaf_1973@yahoo.com
}

How to cite this paper: Khallaf, M. and Shahine, M.S. (2019) Epidemiological Features of Patients with Craniomaxillofacial Fractures: A Single Centre Study. Open Journal of Modern Neurosurgery, 9, 132-144. https://doi.org/10.4236/ojmn.2019.92013

Received: February 1, 2019

Accepted: March 29, 2019

Published: April 1, 2019

Copyright (อ 2019 by author(s) and Scientific Research Publishing Inc. This work is licensed under the Creative Commons Attribution International License (CC BY 4.0).

http://creativecommons.org/licenses/by/4.0/

\section{c) (i) Open Access}

\begin{abstract}
Purpose: It has been shown that cranial injuries associated with facial fractures may cause a great risk of mortality and neurological morbidity, which mainly occurs in young adults. Various studies have been carried out in various countries to study the epidemiology of the cranio maxillofacial injuries but the studies from Egypt are few. The aim of this study was therefore to assess the prevelance, etiology, type of injury, and site of fractures among patient attending Assiut University Hospitals. Material and Methods: Retrospective hospital study was carried out at Trauma unit, Assiut University Hospitals (Single Tertiary Hospital) between January 2010 and December 2017. Radiographs and hospital data of 1745 patients with craniomaxillofacial trauma were gathered and analyzed. The identified fractures, such as, age, gender, etiology of injury, and anatomical sites of fractures were classified as: frontal/skull base, naso-orbital, maxilla, zygoma, and mandible. According to GCS, patients were classified into 3 grades: mild, moderate and severe. Gathered data was coded and entered into a computer and analyzed using SPSS version 22. Result: Overall prevalence of cranio maxillofacial injuries was $3 \%$. Age ranged from 1 - 90 with mean \pm SD $25.75 \pm 15.5$. The greatest number of the patients had 18 to 40 years old $(48.4 \%)$ and most of them were male (M/F ratio was $7: 1)$. The most prevalent causes of the trauma in this study were the road traffic accidents $(67.7 \%)$ and accidental fall $(15 \%)$, respectively. Firearm injuries accounted for fractures in 86 patients $(4.9 \%)$. The most common bone fracture among the patients was the mandibular bone (47.7\%). 837 patients (48\%) required surgical intervention. Conclusions: This retrospective population study demonstrates an insight into the demographics and fracture patterns in craniomaxillofacial trauma patients. The most common etiology of craniomaxillofacial injury was road traffic accidents followed by falls and assaults, suggesting that interventions addressing the prevention of this me-
\end{abstract}


chanism, and treatment of the associated injury patterns, have not been sufficient and require to be revised. The majority of victims were young adult males between the ages of 18 to 40 years. The mandibular bone and maxilla were the most common sites of fracture.

\section{Keywords}

Cranio Maxillofacial, Trauma, Epidemiology, Assiut

\section{Introduction}

The combined craniomaxillofacial fractures are those fractures of fronto maxillary and front nasal areas extending to the base of the skull [1]. Ironically, the face and head are prone to frequent injuries. Due to the close anatomic proximity of maxillofacial bone and cranium, usually the patients with maxillofacial fractures are at an increased risk of and suffer from traumatic head injury simultaneously which can lead to primary or secondary brain damage in case of a miss or late diagnosis in such cases [2] [3]. This makes accurate diagnostic evaluation necessary, especially in cute stage to clarify emergent injuries; to preoperatively plan the reconstruction of functional areas; and to guide the physical, psychological, and social rehabilitation process [4].

Epidemiological data associated with the craniomaxillofacial trauma depend on the demographic data from the population studied, which include the geographic region, socio-economic situation, and time factors which can influence the type and frequency of injuries in the population [5] [6] [7] [8]. Several studies for determination of the prevalence and etiology of craniomaxillofacial traumas have been carried out worldwide with the aim of characterizing patterns, identifying new trends for occurrences of these injuries, planning and evaluating preventive measures and health policies, and developing priority goals for research in this area [9] [10] [11], but the studies from Egypt are few [12].

Craniomaxillofacial fractures result from blunt or penetrating injury. Blunt injuries are far more common, resulting from vehicular accidents altercations, sporting-related trauma, occupational injuries, and falls. Penetrating injuries mainly are the result of gunshot wounds, stabbings, and explosions [13]-[21]

It is important to understand that maxillofacial traumas represent one of the greatest challenges to public health services worldwide, because of their high incidence and significant financial cost involved in their management so the pattern and etiological factors of craniomaxillofacial fractures in Assiut need to be determined as such database is necessary for planning prevention strategies and managemensic medicine experts, but also for emerent. Also; we believe that the findings of this study will be helpful for not only forgency doctors and surgeons.

\section{Patients \& Methods}

This retrospective hospital based, study was carried out on 1745 patients with 
craniomaxillofacial fractures admitted to Trauma unit, Assiut University Hospitals (Single Tertiary Hospital) between January 2010 and December 2017. Data of the admitted injury cases were obtained from the database office at the Trauma Unit of Assiut University Hospitals. The collected data includes basic demographic data of the cases regarding age, sex, residence, occupation, mechanisms of trauma, anatomical sites of fractures, types of management and outcome.

The data were obtained in Excel program. Coding of causes of injuries was carried out using the tenth revision of the international classification of diseases (ICD-10) codes (World health Organization 2010) [22]. Inclusion criteria: All patients who reported to the trauma unit, Assiut University Hospital with maxillofacial fractures (patients who were admitted as well as those who were treated as outpatients) were included in the study. Exclusion criteria consisted of patients who expired before examination, admitted with soft tissue injuries and readmitted with complications were excluded from the study.

According to GCS, patients classified into 3 grades: mild (GCS 13-15), moderate (GCS 9-12) and severe (GCS 3-8) [23]. Fractures of the facial skeleton were classified into mandibular fracture (Symphyseal \& parasymphyseal, body, angle, ramus and condylar fracture), maxillary fractures, zygomatic fracture, frontal bone fractures, nasal bone, nasoethmoidal fractures and multiple site fractures.

CT scan, 3DCT scans are the current imaging standard for evaluating frontal bone fractures. In the multitraumatized patient, craniomaxillofacial and brain CT was often be part of an extensive CT examination including the cervical spine, trunk, and sometimes extremities. Other body segments were imaged as needed to exclude or detect other system injuries. Collaboration is usually arranged between the teamwork according the extent of craniomaxillofacial trauma and mainly depends on the Neurosurgeons, Maxillofacial surgeons. Pediatrician and Oph-thalmic surgeon may have a role.

In the present series, approaches to the craniomaxillofacial fractures were according to the guidelines described in the literature, including repositioning of the displaced fracture segments into anatomic position, with a focus on the lattice supports in relation to each other and to the cranial base. Open reduction and internal fixation with miniplates was done in the cases of displaced fractures. Undisplaced fractures were managed conservatively and provided acceptable functional and aesthetic results. Postoperative CT scans were obtained to assess bony reconstruction and follow-up intracranial injuries.

\subsection{Statistical Analysis}

Data was collected in Excel sheet (Microsoft office 2010), then were analyzed using SPSS version 22 (SPSS, Inc., Chicago, IL). The results were expressed as frequency and percent in qualitative data and mean \pm SD for quantitative data. Chi-square test was used for comparison of qualitative data to express the prevalence of cranio maxillofacial fractures with sociodemographic data, causes, types and anatomical sites of the sustained injuries to the study population. $\mathrm{P}$ 
values less than 0.05 were considered statistically significant.

\subsection{Ethical Consideration}

The study was conducted after getting ethical clearance and the permission from Assiut University Teaching Hospital administration. Thorough explanation of the purpose of the study and how data will be treated with respect and confidentiality was provided to the participants. The study protocol was approved by the ethical committee, faculty of medicine, Assiut University, Egypt.

\section{Results}

Retrospective hospital based study include 1745 patients with combined craniomaxillofacial fractures admitted to trauma unit, Assiut University Hospital between January 2010 to December 2017. A Overall prevalence of cranio maxillofacial injuries was 3\% (total number of patients were 58166). The distribution of craniomaxillofacial by age among the study subjects revealed that the age group 18 - 40 years presented with (48.4\%). There was an overwhelming male patient's ranged preponderance in all age groups $(87.5 \%)$. The overall male: female ratio was 7:1. The most frequently cause of cranio maxillofacial injuries was motor car and motorcycle accident with a proportion of (37.7\%) and (30. \%) respectively. Accidental fall accounted for the fractures in $15 \%$ mostly involving children who fell while playing, elderly people who fell down due to systemic illness, or men Assault and firearm had relatively the same proportional, 5.9\% and $4.8 \%$ respectively. Table 1 shows that $53.2 \%$ of patients GCS were mild (12 15).

Road traffic accident was the most frequent etiology of the traumas found in the present study, predominating among the men-1071 cases. Motor car accidents were more frequent in men-575 cases (87.5\%) compared to 82 women (12.5\%). Accidents with motorcycles happened to 496 men (94.7\%) and 28 women (5.3\%) commonly in age group 18 - 40: 313 cases caused by motor car and 315 cases caused by motor cycle. 182 men and 87 women fell. Fall from height in 140 men $(67.3 \%)$ and 42 women $(32.7 \%)$ respectively. Fall on the ground in 42 males (68.9\%) and 19 women (32.1\%). Fall was common in children (fall from height in 136 cases; $65.4 \%$ and fall on the ground in 39 cases 63.9\%). Interpersonal violence was frequent etiology of the traumas found in the present study, predominating among the men-96 cases (94.1\%) and 6 women (5.9\%), commonly in age group 18 - 40 (59 cases). It is important to stress that this category, rarely occurred in children and elderly population of our sample ( 9 and 5 cases respectively). 79 men (91.9\%) and 7 woman (8.1\%) suffered injuries caused by fire arms. Majority in age group (18 - 40) 56 cases, rarely occurred in children and elderly population of our sample ( 9 and 5 cases respectively) as shown in Tables 2-4.

Glasgow coma scale in different forms of trauma is shown in Table 5.

Mandibular fracture has been showed to be the most affected hard tissue involved with injuries $(47.7 \%)$, followed by the maxillary bone fracture $(19.1 \%)$, 
Table 1. Demographic data of hospitalized injured cases in the studied period (2010: 2017).

\begin{tabular}{|c|c|}
\hline Variable & Cases $=1745$ No. $(\%)$ \\
\hline \multicolumn{2}{|l|}{ Year } \\
\hline - 2010 & - $\quad 286(16.4)$ \\
\hline - 2011 & - $253(14.5)$ \\
\hline - 2012 & - $182(10.4)$ \\
\hline - 2013 & - $202(11.6)$ \\
\hline - 2014 & - $155(8.9)$ \\
\hline - 2015 & - $239(13.7)$ \\
\hline - 2016 & - $190(10.9)$ \\
\hline - 2017 & - $238(13.7)$ \\
\hline \multicolumn{2}{|l|}{ Sex } \\
\hline - Male & - $1527(87.5)$ \\
\hline - Female & - $\quad 218(12.5)$ \\
\hline \multicolumn{2}{|l|}{ Age groups of the patients: } \\
\hline - less than 18 & - $612(35.1)$ \\
\hline - 18 to less than 40 & - $845(48.4)$ \\
\hline - from 40 to less than 60 & - $237(13.6)$ \\
\hline - 60 and more & - $51(2.9)$ \\
\hline Mean \pm SD (range) & $25.75 \pm 15.5(1.90)$ \\
\hline \multicolumn{2}{|l|}{ Occupation of the cases } \\
\hline - no work & - $\quad 341(37.7)$ \\
\hline - worker & - $392(30.0)$ \\
\hline - farmer & - $180(4.6)$ \\
\hline - officer & - $197(4.9)$ \\
\hline - student & - $\quad 411(11.9)$ \\
\hline - child & - $203(3.5)$ \\
\hline - $\quad$ retired & - $21(0.8)$ \\
\hline - others & - $12(0.7)$ \\
\hline \multicolumn{2}{|l|}{ GCS } \\
\hline - Mild & - $929(53.2)$ \\
\hline - Moderate & - $735(42.1)$ \\
\hline - Sever & - $81(4.6)$ \\
\hline \multicolumn{2}{|l|}{ Type of treatment: } \\
\hline - Surgical & - $837(48.0)$ \\
\hline - Conservative & - $908(52.0)$ \\
\hline
\end{tabular}

zygomatic fracture (17.2\%), frontal bone fractures (8.8\%). Other sites for hard tissue involvement were seen in small proportion such as nasal bone, nasoethmoidal fractures and multiple sites injuries $4.3 \%, 2.9 \%$ respectively (Table 6).

\section{Discussion}

All aspects regarding trauma have a great importance in the world today, being among the main causes of morbidity and mortality and Egypt is not different in this aspect. Craniomaxillofacial trauma involves serious esthetic and functional problems that lead to various consequential complications. Epidemiological studies on facial trauma are diverse regarding inclusion criteria for patients and injuries considered, and their results also vary according to factors like geographic 
Table 2. Mechanisms of trauma among hospitalized injured cases in the studied period (2010: 2017).

\begin{tabular}{|c|c|}
\hline Variable & Cases $=1745$ No. $(\%)$ \\
\hline - Motor car accidents & - $\quad 657(37.7)$ \\
\hline - Motor cycle accidents & - $524(30.0)$ \\
\hline - Heavy objects & - $81(4.6)$ \\
\hline - Firearm injuries & - $86(4.9)$ \\
\hline - Fall from height & - $\quad 208(11.9)$ \\
\hline - Fall on the ground & - $61(3.5)$ \\
\hline - Assault from others & - $102(5.8)$ \\
\hline - Train accidents & - $14(0.8)$ \\
\hline - Others & - $12(0.7)$ \\
\hline
\end{tabular}

Table 3. Pattern of trauma in both male and female in the studied sample.

\begin{tabular}{cccccccccc}
\hline \multirow{2}{*}{ Sex } & $\begin{array}{c}\text { Motor } \\
\text { care } \\
\text { accident }\end{array}$ & $\begin{array}{c}\text { Motor } \\
\text { cycle } \\
\text { accident }\end{array}$ & $\begin{array}{c}\text { Heavy } \\
\text { objects }\end{array}$ & $\begin{array}{c}\text { Firearm Fall from } \\
\text { injuries }\end{array}$ & $\begin{array}{c}\text { Fall on } \\
\text { height }\end{array}$ & $\begin{array}{c}\text { Assault } \\
\text { the } \\
\text { ground }\end{array}$ & $\begin{array}{c}\text { Train } \\
\text { others }\end{array}$ & Occident & Others \\
\cline { 2 - 10 } & No. (\%) & No. (\%) & No. (\%) & No. (\%) & No. (\%) & No. (\%) & No. (\%) & No. (\%) & No. (\%) \\
\hline \multirow{2}{*}{ Male } & 575 & 496 & 75 & 79 & 140 & 42 & 96 & 13 & 11 \\
& $(87.5)$ & $(94.7)$ & $(92.6)$ & $(91.9)$ & $(67.3)$ & $(68.9)$ & $(94.1)$ & $(92.9)$ & $(91.7)$ \\
Female & 82 & 28 & 6 & 7 & 68 & 19 & 6 & 1 & 1 \\
& $(12.5)$ & $(5.3)$ & $(7.3)$ & $(8.1)$ & $(32.7)$ & $(32.1)$ & $(5.9)$ & $(7.1)$ & $(8.3)$ \\
\hline
\end{tabular}

Chi square test was used. P-value $<0.0001$.

Table 4. Pattern of trauma in different age groups in the studied sample.

\begin{tabular}{|c|c|c|c|c|c|c|c|c|c|}
\hline \multirow[t]{2}{*}{ Age groups } & $\begin{array}{c}\text { Motor care } \\
\text { Accident }\end{array}$ & $\begin{array}{c}\text { Motor } \\
\text { cycle } \\
\text { accident }\end{array}$ & $\begin{array}{l}\text { Heavy } \\
\text { objects }\end{array}$ & $\begin{array}{l}\text { Firearm } \\
\text { injuries }\end{array}$ & $\begin{array}{c}\text { Fall from } \\
\text { height }\end{array}$ & $\begin{array}{l}\text { Fall on } \\
\text { the } \\
\text { ground }\end{array}$ & $\begin{array}{l}\text { Assault } \\
\text { from } \\
\text { others }\end{array}$ & $\begin{array}{c}\text { Train } \\
\text { accident }\end{array}$ & Others \\
\hline & No. (\%) & No. (\%) & No. (\%) & No. (\%) & No. (\%) & No. (\%) & No. (\%) & No. (\%) & $\begin{array}{l}\text { No. } \\
(\%)\end{array}$ \\
\hline Less than 18 & $\begin{array}{c}221 \\
(33.6)\end{array}$ & $\begin{array}{c}157 \\
(30.0)\end{array}$ & $\begin{array}{c}27 \\
(33.3)\end{array}$ & $\begin{array}{c}11 \\
(12.8)\end{array}$ & $\begin{array}{c}136 \\
(65.4)\end{array}$ & $\begin{array}{c}39 \\
(63.9)\end{array}$ & $\begin{array}{c}9 \\
(8.8)\end{array}$ & $\begin{array}{c}3 \\
(21.4)\end{array}$ & $\begin{array}{c}9 \\
(75.0)\end{array}$ \\
\hline $18 \leq 40$ & $\begin{array}{c}313 \\
(47.6)\end{array}$ & $\begin{array}{c}315 \\
(60.1)\end{array}$ & $\begin{array}{c}36 \\
(44.4)\end{array}$ & $\begin{array}{c}56 \\
(65.1)\end{array}$ & $\begin{array}{c}44 \\
(21.2)\end{array}$ & $\begin{array}{c}12 \\
(19.7)\end{array}$ & $\begin{array}{c}59 \\
(57.8)\end{array}$ & $\begin{array}{c}8 \\
(57.1)\end{array}$ & $\begin{array}{c}2 \\
(16.7)\end{array}$ \\
\hline $40 \leq 60$ & $\begin{array}{c}104 \\
(15.8)\end{array}$ & $\begin{array}{c}46 \\
(8.8)\end{array}$ & $\begin{array}{c}16 \\
(19.8)\end{array}$ & $\begin{array}{c}13 \\
(15.1)\end{array}$ & $\begin{array}{c}20 \\
(9.6)\end{array}$ & $\begin{array}{c}6 \\
(9.8)\end{array}$ & $\begin{array}{c}29 \\
(28.8)\end{array}$ & $\begin{array}{c}3 \\
(21.4)\end{array}$ & $0(0.0)$ \\
\hline 60 and more & $19(2.9)$ & $6(1.1)$ & $2(2.5)$ & $6(7.0)$ & $8(3.8)$ & $4(6.6)$ & $5(4.9)$ & $0(0.0)$ & $1(8.3)$ \\
\hline
\end{tabular}

Chi square test was used. P-value $<0.001$.

Table 5. Glasgow coma scale in different forms of trauma in the studied sample.

\begin{tabular}{|c|c|c|c|c|c|c|c|c|c|}
\hline \multirow[t]{2}{*}{ Age groups } & $\begin{array}{l}\text { Motor care } \\
\text { Accident }\end{array}$ & $\begin{array}{c}\text { Motor } \\
\text { cycle } \\
\text { accident }\end{array}$ & $\begin{array}{l}\text { Heavy } \\
\text { objects }\end{array}$ & $\begin{array}{l}\text { Firearm } \\
\text { injuries }\end{array}$ & $\begin{array}{l}\text { Fall from } \\
\text { height }\end{array}$ & $\begin{array}{l}\text { Fall on } \\
\text { the } \\
\text { ground }\end{array}$ & $\begin{array}{c}\text { Assault } \\
\text { from } \\
\text { others }\end{array}$ & $\begin{array}{c}\text { Train } \\
\text { accident }\end{array}$ & at Others \\
\hline & No. (\%) & No. (\%) & No. (\%) & No. (\%) & No. (\%) & No. (\%) & No. (\%) & & 6) \\
\hline Mild & $299(45.5)$ & $\begin{array}{c}273 \\
(52.1)\end{array}$ & $\begin{array}{c}55 \\
(67.9)\end{array}$ & $\begin{array}{c}58 \\
(67.4)\end{array}$ & $\begin{array}{c}118 \\
(56.7)\end{array}$ & $\begin{array}{c}41 \\
(67.2)\end{array}$ & $\begin{array}{c}71 \\
(69.6)\end{array}$ & $\begin{array}{c}6 \\
(42.9)\end{array}$ & $8(66.4)$ \\
\hline Moderate & $320(48.7)$ & $\begin{array}{c}223 \\
(42.6)\end{array}$ & $\begin{array}{c}24 \\
(29.6)\end{array}$ & $\begin{array}{c}24 \\
(27.9)\end{array}$ & $\begin{array}{c}86 \\
(41.3)\end{array}$ & $\begin{array}{c}18 \\
(29.5)\end{array}$ & $\begin{array}{c}28 \\
(27.5)\end{array}$ & $\begin{array}{c}8 \\
(57.1)\end{array}$ & $4(33.6)$ \\
\hline Sever & $38(5.8)$ & $28(5.3)$ & $2(2.5)$ & $4(4.7)$ & $4(1.9)$ & $2(3.3)$ & $3(2.9)$ & $0(0.0)$ & ) $0(0.0)$ \\
\hline
\end{tabular}

Chi square test was used. P-value $<0.006$. 
Table 6. Frequency of injuries according to the anatomical sites.

\begin{tabular}{lcc}
\hline \multicolumn{1}{c}{ Anatomical sites } & Frequency & Percent \\
\hline -Mandibular fracture & 833 & $47.7 \%$ \\
Symphyseal \& parasymphyseal & 295 & $35.4 \%$ \\
-Body & 185 & $22.2 \%$ \\
-Angle & 177 & $21.4 \%$ \\
Condylar fracture & 150 & $18.1 \%$ \\
Ramus & 26 & $3.1 \%$ \\
Maxillary fractures & 333 & $19.1 \%$ \\
-Zygomatic fracture & 300 & $17.2 \%$ \\
-Frontal bone fractures & 154 & $8.8 \%$ \\
-Nasal bone, nasoethmoidal fractures & 75 & $4.3 \%$ \\
-Multiple site fractures & 50 & $2.9 \%$ \\
\hline
\end{tabular}

location, socioeconomic status and cultural environment.

In this study, 58,166 patients attended Trauma unit, Assiut University Hospitals (Single Tertiary Hospital) between January 2010 to December 2017 and among them $3 \%(n=1745)$ cases presented with cranio maxillofacial injuries. The association between traumatic head injury and maxillofacial fractures has not been firmly established in the literature. The differences and conflicts in studies regarding the association globally are very wide. The prevalence of traumatic head injury in a patient with maxillofacial ranges from $7.6 \%$ to $8.9 \%$ in some studies [24] [25] while in other studies, this percentage can reach up to $86 \%$ in more serious maxillofacial [26]. The variations of the results can refer to the habitual, socioeconomic, cultural differences in the studied populations as well as the differences in the etiology and methodological criteria applied in various studies [2] [24] [27] [28].

Pediatric craniomaxillofacial injuries are less common in comparison with adults as regards, to the anatomical, social and environmental aspects [29]. The lower frequency of facial fractures in children than in adults is generally reported. This is due to the elasticity of bones in children and the presence of tooth buds. In terms of age groups, facial fractures occur most frequently in people of second and third decade which is in concurrence with the other studies [12] [30] [31]. In our series, highest number of men and women suffered trauma in this age group. The possible explanation for this as also reported in literature is that this age group is the most active age group that are involved in different activity such as travelling for day-to-day activities, take part in dangerous exercises and sports, driving motor vehicles carelessly, and are most likely to be involved in violence hence placing them at high risk of sustaining these injuries [32] [33]. As a result of increasing active elderly population, more maxillofacial injuries occur in the population than ever before. The absolute increase in trauma victims in the elderly population relates to more active lifestyles, increased life expectancy and a general increase in the percentage of elderly persons in the population.

Predominance of men in such patient population is a relatively consistent 
finding in most of the studies. Male:female ratio of $7: 1$, as in our study, is comparable with all such studies in which it varies from 2:1 to 8:1 [12] [34] [35]. This is attributed to the fact that men are involved in most of the outdoor activities and work in Egypt and most of the women especially in rural areas are confined to the house works.

Maxillofacial injuries are becoming very common in the urban as well as rural areas. In the developed nations, the major cause of the injuries is the interpersonal violence while in the developing nations it is mainly attributed to road traffic accident [11] [36]. The underlying reasons for that high rate include absence or defects of road traffic regulations and its application, lack of legislation regarding compulsory seat belts and helmet, risky driving, bad road quality, less safety of the vehicles, and increased usage of motor vehicles and cycles. The most important factor is the forbidden of alcohol drinking in Islamic countries according to their religion which may effectively lead to lower rates of assaultrelated maxillofacial fractures, thus making the proportional contribution of road traffic accident higher [37].

Egypt is similar to the majority of African developing countries, with an increasing urban population, an insufficiency of public transport and a non-compliance with speed limits and seat belt laws. In this study, the most frequently cause of cranio maxillofacial injuries was motor car and motorcycle accident with a proportion of $(37.7 \%)$ and $(30 \%)$ respectively. Accidental fall accounted for the fractures in $15 \%$. Assault and firearm had relatively the same proportional, 5.9\% and $4.8 \%$ respectively. Strict road traffic laws and implementation of safety norms like mandatory seat belts, air bags, helmet wearing for motorized two-wheelers and speed limits have greatly reduced maxillofacial injuries due to RTA in the developed countries [30] [38].

Although fall was the third category in the order of frequency, it was the one which proved to be the most important trauma mechanism in age group. Aging is characterized by the gradual reduction in biological functions, with multiple sensory deficits, visual and auditory among them, changes in cognition and memory, and bone and muscle disorders increasing the risk of falls; while in children, a number of factors cause falls, since it is not only neurological centers which are involved, but also all those associated with balance and movement which are still being developed, and children do not know the difference between dangerous actions and the safe ones [39] [40] [41]. In the developing countries, interpersonal violence is the second leading cause of maxillofacial injuries [36] [38]. But in our study the second most common reason for the injury was accidental falls (16.0\%).

Mandible (47.7\%) and maxilla (19\%) fractures were the most prevalent injuries found in our study. Mandible fracture was the one which occurred more often in all trauma categories, except for non-lethal weapons and "others". The results from the present study are in agreement with the literature [40] [42] [43]. Shankar et al. [44] in a retrospective analysis showed that the second most 
common type of fracture in maxillofacial region was maxillary fracture which is in agreement with our study. Minor differences in the frequency of fractures can be caused by variations in the etiology of fracture in various studied. The vulnerability of this bone can be explained by its anatomically prominent position in the facial skeleton.

In the present study, surgical treatment was required in $48 \%$ of the cases, when compared to the conservative one, and this data was statistically insignificant. The indications for surgery included simple or complex factures with skull involvement, associated injuries, bruises and sutures for scalp laceration. The surgical approach is in agreement with the present protocol from the department of Neurosurgery and maxillofacial surgery, following the world trend, including reduction, immobilization and fixation to the proper anatomical position of the fragments which shifted in relation to the other bones and the skull base. Non-shifted fractures are treated conservatively and the shifted ones are treated by open reduction and rigid internal fixation with miniplates [45] [46] [47].

We faced some limitations in this study. Study subjects were ascertained along with many study variables using electronic medical records. These sources were not primarily designed for research purposes and could have had missing or incorrectly entered information. We did not have access to the records of patients who died at the scene, as no medical records were available for these cases. Also, the histories of accidents and other injuries were provided by victims, witnesses, or paramedic personnel at the scene which may be unreliable in some cases. Although we tried to elucidate the exact causes of the injuries and what had happened at the trauma scenes, it is likely that some patients or their accompanied persons were not able to remember the trauma details completely or accurately. Also it is a single Centre study it may be helpful to enroll more medical centers from major cities and smaller cities, as well as both rural and urban areas, for better understanding of the causes and extents of craniomaxillofacial injuries in Egypt.

\section{Conclusion}

Epidemiological characteristics of facial fractures in this study are similar to that generally reported in developing countries. Facial trauma happened most frequently to young adult men. Most of the injuries were due to RTA. The most common anatomical sites affected by primary fractures on the face were the mandible. This clinical and epidemiological bank of data could gave the ground for health care providers to precisely plan the management options and goals in this patients and establishment of preventional health programs to reduce the impact of these injuries in the community. We recommend improving public awareness by applying road traffic regulations, encouraging the rules for compulsory usage of seat belts and helmet, avoiding risky driving, and enhancing road quality. 


\section{Acknowledgements}

We would like to thank Dr. Medhat Elaraby from the Community Medicine and Epidemiology Department, Faculty of Medicine, Assiut University for his kind assistance in providing statistical support during the analysis of the study data.

\section{Conflicts of Interest}

There are no conflicts of interest.

\section{Financial Support and Sponsorship}

None.

\section{References}

[1] Matras, H. and Kuderna, H. (2000) Combined Cranio-Facial Fractures. Journal of Maxillofacial Surgery, 8, 52-59.

[2] Zandi, M. and Seyed Hoseini, S.R. (2013) The Relationship between Head Injury and Facial Trauma: A Case-Control Study. Journal of Oral and Maxillofacial Surgery, 17, 201-207.

[3] Grant, A.L., Ranger, A., Young, G.B. and Yazdani, A. (2012) Incidence of Major and Minor Brain Injuries in Facial Fractures. Journal of Craniofacial Surgery, 23, 1324-1328. https://doi.org/10.1097/SCS.0b013e31825e60ae

[4] Kostakis, G., Stathopoulos, P., Dais, P., Gkinis, G., Igoumenakis, D., Mezitis, M., et al. (2012) An Epidemiologic Analysis of 1142 Maxillofacial Fractures and Concomitant Injuries. Oral Surgery, Oral Medicine, Oral Pathology and Oral Radiology, 114, S69-S73. https://doi.org/10.1016/j.tripleo.2011.08.029

[5] Al-Sayed, F.T. and Shoeib, M.A. (2015) Pediatric Craniomaxillofacial Injuries: Concept of Treatment. The Medical Journal of Cairo University, 83, 217-224.

[6] Bither, S., Mahindra, U., Halli, R. and Kini, Y. (2008) Incidence and Pattern of Mandibular Fractures in Rural Population: A Review of 324 Patients at a Tertiary Hospital in Loni, Maharashtra, India. Dental Traumatology, 24, 468-470.

[7] Al-Khateeb, T. and Abdullah, F.M. (2007) Craniomaxillofacial Injuries in the United Arab Emirates: A Retrospective Study. Journal of Oral and Maxillofacial Surgery, 65, 1094-1101. https://doi.org/10.1016/j.joms.2006.09.013

[8] Lee, J.H., Cho, B.K. and Park, W.J. (2010) A 4-Year Retrospective Study of Facial Fractures on Jeju, Korea. Journal of Cranio-Maxillofacial Surgery, 38, 192-196. https://doi.org/10.1016/j.jcms.2009.06.002

[9] Wasiu, L., Akinola, L., Mobolanle, O. and Olutayo, J. (2005) Trends and Characteristics of Oral and Maxillofacial Injuries in Nigeria: A Review of the Literature, Head \& Face Medicine, 1, 1-9. https://doi.org/10.1186/1746-160X-1-7

[10] Al-Ahmed, H.E., Jaber, M.A., Abu Fana, S.H. and Karas, M. (2004) The Pattern of Maxillofacial Fractures in Sharjah, United Arab Emirates: A Review of 230 Cases. Oral Surgery, Oral Medicine, Oral Pathology, Oral Radiology, and Endodontology, 98, 166-170. https://doi.org/10.1016/j.tripleo.2004.01.020

[11] José, R., Ênio, J.S., Fabrício, D., Erica, T. and Cláudio, R. (2010) Risk Factors for Maxillofacial Injuries in a Brazilian Emergency Hospital Sample. Journal of Applied Oral Science, 18, 23-29. https://doi.org/10.1590/\$1678-77572010000100006

[12] Hassan, N.A., Kelany, R.S., Emara, A.M. and Amer, M. (2010) Pattern of Crani- 
omaxillofacial Injuries in Patients Admitted to Tanta University Hospital-Egypt. Journal of Forensic and Legal Medicine, 17, 26-32. https://doi.org/10.1016/j.jflm.2009.07.008

[13] Hasan, N. and Colucciello, S.A. (2004) Maxillofacial Trauma. In: Tintinalli, J.E., Gabor, K.D. and Stapczynski, S.J., Eds., Emergency Medicine: A Comprehensive Study Guide, 6th Edition, The McGraw-Hill Companies Inc., 1583-1590.

[14] McKay, M.P. (2006) Facial Trauma. In: Marx, J.A., Hockberger, R.S., Walls, R.M., Eds., Rosen's Emergency Medicine, Concepts and Clinical Practice, 6th Edition, Mosby Elsevier, Philadelphia, PA, 382-398.

[15] Kummoona, R.K. (2011) Missile War Injuries of the Face. Journal of Craniofacial Surgery, 22, 2017-2021. https://doi.org/10.1097/SCS.0b013e318231978a

[16] Hoppe, I.C., Kordahi, A.M., Paik, A.M., Lee, E.S. and Granick, M.S. (2014) Examination of Life-Threatening Injuries in 431 Pediatric Facial Fractures at a Level 1 Trauma Center. Journal of Craniofacial Surgery, 25, 1825-1828. https://doi.org/10.1097/SCS.0000000000001055

[17] Hasheminia, D., Kalantar Motamedi, M.R., Hashemzehi, H., Nazeri, R. and Movahedian, B. (2015) A 7-Year Study of 1,278 Patients with Maxillofacial Trauma and Cerebrospinal Fluid Leak. Journal of Oral and Maxillofacial Surgery, 14, 258-262. https://doi.org/10.1007/s12663-014-0630-Z

[18] Vu, A.T., Patel, P.A., Chen, W., Wilkening, M.W. and Gordon, C.B. (2015) Pediatric Frontal Sinus Fractures: Outcomes and Treatment Algorithm. Journal of Craniofacial Surgery, 26, 776-781. https://doi.org/10.1097/SCS.0000000000001276

[19] Peltola, E.M., Koivikko, M.P. and Koskinen, S.K. (2014) The Spectrum of Facial Fractures in Motor Vehicle Accidents: An MDCT Study of 374 Patients. Emergency Radiology, 21, 165-171. https://doi.org/10.1007/s10140-013-1173-1

[20] Coppola, S., Froio, S., Merli, G. and Chiumello, D. (2015) Maxillofacial Trauma in the Emergency Department: Pearls and Pitfalls in Airway Management. Minerva Anestesiologica, 81, 1346-1358.

[21] Rodriguez, E.D., Stanwix, M.G., Nam, A.J., et al. (2008) Twenty-Six-Year Experience Treating Frontal Sinus Fractures: A Novel Algorithm Based on Anatomical Fracture Pattern and Failure of Conventional Techniques. Plastic and Reconstructive Surgery, 122, 1850-1866. https://doi.org/10.1097/PRS.0b013e31818d58ba

[22] World health Organization (2013) World Health Statistics. http://www.who.int/whosis/whostat/2010/en/index.html

[23] Graham, T. and Bryan, J. (1974) Assessment of Coma and Impaired Consciousness. A Practical Scale. The Lancet, 2, 81-84.

[24] Arslan, E.D., Solakoglu, A.G., Komut, E., Kavalci, C., Yilmaz, F., Karakilic, E., et al. (2014) Assessment of Maxillofacial Trauma in Emergency Department. World Journal of Emergency Surgery, 9, 1-7. https://doi.org/10.1186/1749-7922-9-13

[25] Zhou, H.-H., Liu, Q., Yang, R.-T., Li, Z. and Li, Z.B. (2015) Traumatic Head Injuries in Patients with Maxillofacial Fractures: A Retrospective Case-Control Study. Dental Traumatology, 31, 209-214. https://doi.org/10.1111/edt.12165

[26] Alves, L.S., Aragão, I., Sousa, M.J. and Gomes, E. (2014) Pattern of Maxillofacial Fractures in Severe Multiple Trauma Patients: A 7-Year Prospective Study. Brazilian Dental Journal, 25, 561-564. https://doi.org/10.1590/0103-6440201302395

[27] Salentijn, E.G., Peerdeman, S.M., Boffano, P., van den Bergh, B. and Forouzanfar, T. (2014) A Ten-Year Analysis of the Traumatic Maxillofacial and Brain Injury Patient in Amsterdam: Incidence and Aetiology. Journal of Cranio-Maxillofacial Surgery, 
42, 750-710. https://doi.org/10.1016/j.jcms.2013.12.008

[28] Mulligan, R.P., Friedman, J.A. and Mahabir, R.C. (2010) A Nationwide Review of the Associations among Cervical Spine Injuries, Head Injuries, and Facial Fractures. The Journal of Trauma: Injury, Infection, and Critical Care, 68, 587-592. https://doi.org/10.1097/TA.0b013e3181b16bc5

[29] Manson, P.N., Crawley, W.A., Yaremchuk, M.J., Rochmang, M., Hoopes, J.E. and French, J.R.J.H. (1985) Midface Fractures: Advantages of Immediate Extended Open Reduction and Bone Grafting. Plastic and Reconstructive Surgery, 76, 1-12.

[30] Bakardjiev, A. and Pechalova, P. (2007) Maxillofacial Fractures in Southern Bulgaria-A Retrospective Study of 1706 Cases. Journal of Cranio-Maxillofacial Surgery, 35,147-150. https://doi.org/10.1016/j.jcms.2007.01.005

[31] Ugboko, V.I., Olasoji, H.O., Ajike, S.O., Amole, A.O. and Ogundipe, O.T. (2002) Facial Injuries Caused by Animals in Northern Nigeria. British Journal of Oral and Maxillofacial Surgery, 40, 433-437. https://doi.org/10.1016/S0266-4356(02)00181-X

[32] Khan, A.A. (1988) A Retrospective Study of Injuries to the Maxillofacial Skeleton in Harare, Zimbabwe. British Journal of Oral and Maxillofacial Surgery, 26, 435-439.

[33] Magennis, P., Shepherd, J., Hutchison, I. and Brown, A. (1998) Trends in Facial Injuries: Increasing Violence more than Compensates for Decreasing Road Trauma. $B M$ J, 316, 325-332. https://doi.org/10.1136/bmj.316.7128.325a

[34] Chandra Shekar, B.R. and Reddy, C. (2008) A Five-Year Retrospective Statistical Analysis of Maxillofacial Injuries in Patients Admitted and Treated at Two Hospitals of Mysore City. Indian Journal of Dental Research, 19, 304-308.

[35] Subhasraj, K., Nandakumar, C. and Ravindran, C. (2007) Review of Maxillofacial Injuries in Chennai, India: A Study of 2748 Cases. British Journal of Oral and Maxillofacial Surgery, 45, 637-639. https://doi.org/10.1016/j.bjoms.2007.03.012

[36] Cheema, S.A. and Amin, F. (2006) Incidence and Causes of Maxillofacial Skeletal Injuries at the Mayo Hospital in Lahore, Pakistan. British Journal of Oral and Maxillofacial Surgery, 44, 232-234. https://doi.org/10.1016/j.bjoms.2005.05.017

[37] Adsett, L. (2011) Patterns and Trends in Facial Fractures in New Zealand. Ph.D. Thesis, University of Otago, Otago, New Zealand.

[38] Van Beek, G.J. and Merkx, C.A. (1999) Changes in the Pattern of Fractures of the Maxillofacial Skeleton. International Journal of Oral and Maxillofacial Surgery, 28, 424-428. https://doi.org/10.1016/S0901-5027(99)80055-1

[39] Wulkan, M., Parreira Jr., J.G. and Botter, D.A. (2005) Epidemiologia Do Trauma Facial. Revista da Associação Médica Brasileira, 51, 290-295. https://doi.org/10.1590/S0104-42302005000500022

[40] Montovani, J.C., Campos, M.P., Gomes, M.A., Moraes, V.R.S., Ferreira, F.D. and Nogueira, E.A. (2006) Etiologia e incidência das fraturas faciais em adultos e crianças: Experiência em 513 casos. Brazilian Journal of Otorhinolaryngology, 72, 235-241. https://doi.org/10.1016/S1808-8694(15)30061-6

[41] Güzel, A., Karasalihoglu, S. and Küçükugurluorglu, Y. (2007) Evaluation of the Fall Related Trauma Cases Applied to Our Pediatric Emergency Department. Ulusal Travma ve Acil Cerrahi Dergisi, 13, 211-216.

[42] Tussi, R., Stefenon, M., Junior, R.T. and Ávila, G.V. (2000) Face Fractures. Jornal Brasileiro de Medicina,14.

[43] Kelley, P., Crawford, M., Higuera, S. and Hollier, L.H. (2005) Two Hundred Ninety-Four Consecutive Facial Fractures in an Urban Trauma Center: Lessons Learned. Plastic and Reconstructive Surgery, 116, 42e-49e. 
[44] Shankar, A.N., Shankar, V.N., Hegde, N. and Rajendra Prasad, S. (2012) The Pattern of the Maxillofacial Fractures-A Multicentre Retrospective Study. Journal of Cranio-Maxillofacial Surgery, 40, 675-679. https://doi.org/10.1016/j.jcms.2011.11.004

[45] Hogg, N.J., Stewart, T.C., Armstrong, J.E. and Girotti, M.J. (2000) Epidemiology of Maxillofacial Injuries at Trauma Hospital in Ontario, Canada, between 1992 and 1997. The Journal of Trauma: Injury, Infection, and Critical Care, 49, 425-432. https://doi.org/10.1097/00005373-200009000-00007

[46] Rajendra, P.B., Mathew, T.P., Agrawal, A. and Sabharawal, G. (2009) Characteristics of Associated Craniomaxillofacial with Head Injuries: An Experience with 100 Cases. Journal of Emergencies, Trauma, and Shock, 2, 89-94. https://doi.org/10.4103/0974-2700.50742

[47] Ansari, M.H. (2004) Maxillofacial Fractures in Hamedan Province Iran: A Retrospective Study (1987-2001). Journal of Cranio-Maxillofacial Surgery, 32, 28-34.

https://doi.org/10.1016/j.jcms.2003.07.010 